cultural and historical studies. On the second expedition, Mr. L. P. Kirwan, a well-known archæologist, will visit the Aden Protectorate for the purpose of inspecting and examining a number of archæological sites between Aden and Lahej. He will visit Amadiya on the Audhali Plateau, which will be surveyed, and the ruins of Qohlan in Wadi Beihan. Mr. Kirwan will also examine and report on the archæological material in the Aden Museum, which is now in process of being reorganized.

\section{Exhibition of Chinese Art}

AN exhibition has been arranged in the North Court of the Victoria and Albert Museum, South Kensington, which illustrates comprehensively the whole range of Chinese art from the prehistoric period at about 3000 B.c. down to modern times. With the exception of a small series to be seen in the Department of Ceramics, this exhibition includes all the objects of Chinese art of all kinds now in the possession of the Museum. It includes the Museum's share of the Eumorfopoulos collection, which provides some of the most striking and widely known exhibits. The arrangement of the exhibition is chronological and cultural. Each exhibit is grouped with others, whatever their character or material, whether of jade, textile, painting or pottery, provided they belong to the same period and are of the same cultural origin. The first and earliest exhibit is a neolithic pot of about 3000 B.C. A special feature of the exhibition is the important collection of ritual bronzes, which has been provided with special caselabels incorporating small photographs, illustrating the main features of style. A collection of Buddhist sculpture of the fifth and sixth century A.D. is on loan from Baron von der Heydt. Especially noteworthy are two wooden sculptures, one a figure of Kuan Yin, Goddess of Mercy, dating from the twelfth century, and a statue of a seated man, belonging to the fifteenth century. The exhibition is to be permanently on view.

\section{British Museum (Bloomsbury) : Recent Acquisitions}

Accessions to the collections of antiquities and ethnographical objects in the British Museum (Bloomsbury) of exceptional interest were reported at the meeting of the Trustees on March 11. Of these one is a remarkably fine example of the Irish twisted gold torque, which has been accepted on loan for temporary exhibition from the Duke of Westminster. It is made from a single bar of gold, 50 inches long and weighing $26 \mathrm{oz}$. It has been chiselled and beaten into four flanges and then twisted and bent into a circle. The ends are recurved to fit into one another to form a fastening. It is of a type characteristic of the Middle Bronze Age and dates from about 1200 B.c. It was found in 1816 at Bryn Sion Farm, Flintshire. Another accession to the Department of British Antiquities is a collection of fragments of pots of dark earthenware, freely ornamented towards the top with hatchings, pitting, and finger-nail marks, presented by Mr. J. P. T.
Burchell. They were excavated by him in the Ebbs. fleet Valley, Kent, at a depth of $10 \mathrm{ft}$. in stratigraphical conditions, which make it certain that this pottery is older than the neolithic period as at present understood. It is possible that this may prove to be the oldest pottery as yet found in Britain. It would seem to be connected with mesolithic types found on the Continent, such as those from the Danish kitchenmiddens. It differs from British 'Neolithic A', and may indeed prove to be a predecessor of 'Peterborough' ware. Another accession of considerable archæological interest is a human face, almost circular in outline, carved on a piece of Bath stone found near Charterhouse-on-Mendip. It has almondshaped eyes and a small round hole for a mouth. It dates from the period of Roman occupation; but is thought to represent a native barbaric tradition. Of the ethnographical accessions the most striking is a wooden totenic figure of an eagle made by the Siwash Indians of Vancouver Island. It stands about four feet high, with wings half-spread, and is painted in gaudy colours, and has a fierce human face painted on the breast.

\section{British Museum (Natural History): Recent Acquisitions}

The Mineral Department of the British Museum (Natural History) has acquired through Mr. Arthur Russell a small collection of foreign minerals from the collection of Philip Rashleigh, F.R.S., of Menabilly, near Fowey, Cornwall (1729-1811). The main part of the Rashleigh Collection is in the Truro Museum. Mr. Arthur Champion has collected rocks from various localities on a remarkable motor journey he made in 1937 from Dakar to Nairobi. The collection includes specimens from French West Africa and the Belgian Congo as well as from Senegal, Gold Coast and Nigeria. A fine specimen of the mineral thortveitite has been received from Prof. T. Vogt of Trondhjem, Norway, and suitable specimens have been sent him in exchange.

\section{Broadcasting in 1938}

THE report of the Governors of the British Broadcasting Corporation for the year ended December 31, 1938, as presented to His Majesty's PostmasterGeneral, has recently been published as a white paper (Cmd. 5951. London: H.M. Stationery Office. $6 d$. net). The scope of the report is indicated by the headings of the main sections into which it is divided, namely, programmes, public relations, engineering and administration. During the year under review, the Corporation suffered a loss by the resignations of its first director-general, Sir John Reith, and of the deputy director-general, Vice-Admiral Sir Charles Carpendale. Mr. F. W. Ogilvie was appointed to the first position, while Mr. C. G. Graves became the new deputy director-general. The staff of the B.B.C. is now more than four thousand, and these have provided to nearly nine million licensed listeners a home broadcasting service of some 79,500 hours in 1938, with the remarkably small breakdown time of 0.023 per cent. In addition, nearly 33,000 hours 